\title{
Analyzing the Impact of Financial Services Authority (0JK) Regulations in Supporting Economy Recovery During Covid-19 Pandemic: Evidence from Indonesia
}

\author{
Evi Aryati Arbay ${ }^{*}$ and Lusita Astuti Nusantari² \\ London School of Public Relation, Jakarta, Indonesia \\ *Corresponding Author: Evi Aryati Arbay; 19210320043@lspr.edu
}

\begin{abstract}
COVID-19 has disrupted economic growth and business conditions globally including in Indonesia. One of the most obvious impacts is in the banking sector as many bank debtors have lost their livelihoods. This situation affects the quality of bank assets and profitability. An increase of non-performing loans experienced by some national banks has decreased the capability to generate optimal profit from bank operations that normally would keep the banks healthy, liquid, solvent, and in a profitable state. To strengthen the stability of Indonesian financial services and support the national economic recovery effort, the Financial Services Authority (OJK) issued several regulations on macroprudential policy relaxation and stimulus provision. The regulations ensure that banks are capable to control the bad credit of the debtors affected by the COVID-19 pandemic. This study aims to analyze the impact of Financial Service Authority Regulations on the quality of banking credit in supporting the Indonesian economic recovery during the COVID-19 pandemic. This is a qualitative study using a critical thinking analysis method to prove the assumption of Keynesian economic theory, which state that in a recession expansionary fiscal policy can stimulate economic activity. The results of this study indicate that the Financial Services Authority regulations have shown an impact in supporting the Indonesian economy recovery efforts amid the COVID-19 pandemic, which can be seen through the stability of the financial system. Further empirical and quantitative studies are needed to confirm the study findings.
\end{abstract}

Keywords: Risk Management; Financial Services Authority (OJK); Banking Credit; COVID-19; Indonesia Banking COVID-19 Stimulus

\section{INTRODUCTION}

In early 2020, Coronavirus Disease 2019 (COVID-19) hit the world, and the virus transmission became difficult to control (Megatsari, et. al., 2020). The disease that first occurred in Wuhan, China, has had severe effects in social, political, and economic sectors throughout the world (Li, et. al., 2020). Few months after the outbreak, according to Lupia, et. al. (2020), the impact of COVID-19 has damaged asset quality and profitability of banks in the Asia-Pacific region and still disrupting the economic growth and business conditions. Therefore, the quality of Bank assets will have an impact and the cost of Banking credit will rise, thus affecting Bank's profitability. This COVID-19 has caused a global pandemic affecting the financial system across the globe. Nearly all countries including Indonesia have taken immediate measures to control this unpredicted situation. The measures to contain and mitigate the virus have had an immediate and profound impact, (Guerrieri et al., 2020). Based on experience in all countries, when experiencing economic disruption, one solution is to carry out an economic stimulus program. Stimulus economics is the use of changes in monetary policy or fiscal to start growth during a recession. Governments can achieve these using tactics such as lowering interest rates, increasing government spending, and easing various policies (Hayes, 2020).

Banking credit is one of the most severely affected sectors. It is evident that national economic growth is an important factor to improve the quality of banking credit. Optimal economic growth and efforts to reduce poverty rates remain challenging issues for Indonesia (Caraka, et. al., 2020). As an effect of globalization, people's needs are constantly increasing while the source of income is no longer sufficient (Al-Nimri \& Altarawneh, 2020) in this pandemic. Therefore, the bank credit facility is the most in-demand by the public to meet financial needs (Supriatna, 2020).

To achieve optimal economic growth, the implementation of economic development must pay more attention to the harmony, and balance of the elements of equitable development, economic growth, and national stability. One of the facilities that has a strategic role in harmonizing and balancing each element of the development trilogy is the banking sector. Yong \& Xingkai (2016) stated that this strategic role is due to the main function of the bank as a facility that can collect and channel public funds effectively and efficiently supporting the implementation of national development. The banking sector helps increase economic stability. 
With the increasing need for banking services, the existing banking movement needs to be adjusted to deal with the current challenges so that it can accommodate the demands of banking service development (Marks, 2017). The community carries out various innovations to open different kinds of new business fields. The community needs additional funds such as loan credit facilities to develop their business activities. According to Disemadi \& Shaleh (2020), credit facilities can provide benefits although on the other hand uncertain global conditions amid the COVID-19 pandemic very much influence economic development. Something that is expected to run smoothly can hamper the current pandemic condition. Loans extended by banks and other financial institutions are intended to provide additional funds, so that they can provide benefits for both parties.

The provision of credit allows many opportunities to create new jobs because credit has given opportunities for people to develop a new business. Therefore, it is expected that the unemployment rate will decrease through the distribution of funds to the public. The main objective of a nation is to improve the welfare of its citizens. It can be achieved with the establishment of the new jobs supported by the banking credit. All of these activities are carried out as an effort to help accelerate the equitable distribution of economic growth so that it can increase people's living standards.

The condition also causes banks to face credit losses because the exposure to extended credit will be weaker due to a lack of demand for credit (Mentari \& Putri, 2020). In early 2020, the Financial Services Authority continued to pay close attention to the impact of COVID-19 which had the potential to limit public activities and interactions, thus affecting the ability of bank debtors to pay their obligations (Pati, 2020). The Financial Services Authority then provides incentives to the banking industry whose debtors are affected by the coronavirus in the form of determining credit quality from three pillars to only one pillar, namely the debtor's ability to pay their credits. (Susilawati, Falefi \& Purwoko, 2020).

Generally, banking business activities pose many risks and therefore banking business must be strictly regulated. When the loan repayment agreement is at risk of default, this refers to a non-performing loan situation. A non-performing loan can measure the ability of bank management to manage bad credit issued by banks. When the non-performing loans are getting higher it means the quality of banking credit will get worse and it will cause a number of problematic/bad loans to increase (Gusti, 2020). The increase of non-performing loans has made some national banks losing their ability to generate optimum profit from bank operations. The non-performing loans reduce not only the income of a bank but also affect the operational funds and bank liquidity, thereby disrupting the health of the bank and ultimately leading to loss of depositors as the bank customers (Disemadi \& Shaleh, 2020).

This is intended to maintain control of bank's bad credit from debtors who are affected by the COVID-19 outbreak. According to Susilawati, Falefi \& Purwoko (2020), under normal conditions, there are three pillars to determine credit quality, including accuracy in paying, the debtor's business prospects, and the debtor's financial condition. There has been an increase in the number of non-performing loans since March 2020, where the debtor group who was in arrears for at least 1-2 months rose sharply to $27.3 \%$ year on year, the number of non-current credit groups and bad credit groups increased by 19.10\% (Djalante, et. al., 2020). The economic sector has been affected badly. The economic sector is deteriorating including many bank debtors have lost their livelihoods, making it difficult for them to pay off their debts. Halkia, et. al. (2020) explain banks must be prepared to face credit risk, which means that there is a possibility of non-performing loans.

To strengthen the stability of Indonesian financial services and support the national economic recovery effort, the Financial Services Authority (OJK) issued several regulations on macroprudential policy relaxation and stimulus provision. To keep banks in a healthy, liquid, solvent, and profitable condition, the Financial Services Authority issued a Financial Services Authority Regulation Number 11/P0JK.03/2020 concerning National Economic Stimulus as a Countercyclical Policy on the Impact of the Spread of Coronavirus Disease 2019. It is explained in Article 2 paragraph 1 and paragraph 2 that banks can implement policies to support economic growth stimulus for debtors affected by COVID-19. The regulations stipulate some arrangements regarding policies to determine the quality of bank assets and policies for the restructuring of credit or financing. Moreover, Article 5 paragraph 1 describes that the quality of restructured credit is streamlined starting from the credit restructuring period. This policy is good for economic recovery, as described by Horton (2020) that an effective and efficient allocation mechanism for funding sources provides economic benefits. According to Goodell (2020), banks can function as intermediary institutions as a source of financing for business, both in the form of investment and production to encourage economic growth.

Taking into account the strategic role of banking institutions in Indonesia in achieving national development goals during the COVID-19 pandemic, it is necessary to carry out effective guidance and supervision on the implementation of the financial authority regulations. It should be done based on a solid foundation of motion to be able to function efficiently, healthily, naturally, and to be able to deal with global competition. It should properly protect funds entrusted by the community and channel public funds into productive fields for the achievement of development targets. Keynesian economics theory supports these kinds of regulations, which argue that the impact of an economic crisis or recession can be reduced with an increase in government spending (Hayes, 2020). This study aims to analyze the impact of financial service authority regulations against the quality of banking credit in improving the Indonesian economy amid the COVID-19 pandemic. 


\section{METHOD}

\section{- Research Design and Approach}

This is a qualitative study using a critical thinking analysis method to test an economic theory applied during a crisis caused by the COVID-19 pandemic. According to Creswell (2017), critical thinking analysis is applied to address problems and to provide a solution in solving the problem. It is an important part of analyzing literature studies to answer critical questions that lead to caution by always evaluating and analyzing information obtained to produce the right decisions and answers. Therefore, the author examines relevant information, collected official published data, and checked if the information is logically stated. The results of this study confirm the assumption of Keynesian economic theory, which stated that in a recession expansionary fiscal policy can stimulate economic activity and eventually support the national economic recovery during the COVID-19 pandemic.

\section{- Setting}

The primary and secondary data resources used in this study obtained from scientific journal literature discussing the study topic with relevant and contradictory research results as well as documents from Bank Indonesia and the Financial Services Authority policy publication issued during the COVID-19 pandemic.

\section{- Data Collection Technique and Data Analysis}

The data collection techniques used in this study include 1.) Finding suitable sources of scientific journals; 2.) Conducting concept mapping, theory, and opinion analysis; 3.) Link and match against all kinds of perspectives needed; and 4.) Identify and critically sort out the appropriate results of previous studies (Trisliatanto, 2020). The analytical techniques used in critical thinking analysis according to Taylor, Bogdan \& DeVault (2015) are as follows: 1.) Measuring the quality of a source; 2.) Determine between the identification of relevant and irrelevant information; 3.) Distinguishing facts from judgments; 4.) Identifying and evaluating unspoken opinions; 5.) Identifying existing errors or biases; 6.) Identifying viewpoints, and 7.) Evaluating the evidence obtained to support the opinion.

\section{RESULTS AND DISCUSSION}

- Banking Credit Quality during the COVID-19 Pandemic and Its Implications on Economy Recovery On 15 March 2020, Indonesia announced 117 confirmed COVID-19 cases and President Joko Widodo called on the Indonesian population to conduct social distancing measures. The President signed Government Regulation Number 21 of 2020, which regulates large-scale social restrictions in response to COVID-19. The restriction policy has disrupted national economic activity. It caused an increase in the unemployment rate causing poverty and decreased public welfare across the globe (Anderson, et. al., 2020; Adhikari, et. al., 2020). The increasing number of COVID-19 cases further affects the national economic growth indicated by decreased state revenues, increased state spending and financing (Goodell, 2020). The Indonesian Finance Ministry stated that the Indonesian Governments' budget experienced a deficit until July 2020, which reached IDR 330,2 million or 2,01\% of gross domestic product (GDP). Indonesian Governments' income only reaches IDR 922,2 million while the national spending increased to IDR 1,252 trillion used for the National Economic Recovery Program. COVID-19 has also impacted the community's economy, especially for motorcycle taxi drivers, taxi drivers, and actors of Micro, Small, and Medium Enterprises (MSMEs) who must pay bank credit instalments (Caraka, et. al., 2020). The COVID-19 outbreak has a direct and indirect impact on all sectors of the economy both nationally and globally (Barcelo, 2020). According to Gusti (2020), business transformation is needed to capture different opportunities that occur due to consumer behaviour changes. Therefore, the Indonesian Government in making new policies, with regards to the COVID-19 outbreak, is expected to provide clearer regulations and take into account the capacity of banks (Donthu \& Gustafsson, 2020). It is also hoped that the debtors will not take advantage of the situation by not paying the obligatory instalments. Debtors must also have the awareness to pay the instalments that have become their obligations if they are deemed capable and do not experience difficulties to fulfil their obligations to banks and other financial institutions. To respond to this situation, the Indonesian Financial Services Authority and all relevant key stakeholders in the banking sector have worked hand in hand to mitigate the impacts that cause this pandemic, (Bank Indonesia, 2020).

- Implementation of Financial Services Authority Regulations and Policies on Quality of Banking Credit The assessment of the Financial Services Authority on the impact of the pandemic on the national economy and the financial services sector shows that there are still some challenges amidst high uncertainty over the end of the pandemic. The Financial Services Authority assesses that the COVID-19 pandemic raises various risks that affect the financial system, namely default debtors, investor outflows, liquidity risk, and capital risk The Financial Services Authority is strongly committed to supporting programs to accelerate national economic recovery and it is ready to issue a measured and timely banking stimulus policy to maintain the momentum of national economic recovery. The regulations issued to support the government. The 2020 annual report of Bank Indonesia stated that the policy stimuli were applied to support the government in accelerating domestic economic recovery which includes (i) relaxing regulations concerning loan restructuring for individuals, MSMEs and corporate borrowers impacted by Covid-19; (ii) relaxing the enforcement of administrative sanctions on the financial services industry for late payment in the form of fines and/ or interest during emergencies caused by Covid-19 transmission in Indonesia: and (iii) various other follow-up actions to strengthen the authority stipulated in Act No. 2 of 2020. 
The stimulation of this arrangement is applied for state-owned banks only because the government only allocates funds to state-owned banks for credit relaxation, prioritizing MSMEs (Lassa, 2019). The total of COVID-19 restructured credit reached IDR 951.2 trillion from around 7.53 million debtors, consisting of 5.80 million debtors from Micro, Small, and Medium Enterprises with a value of IDR 382 trillion and 1.73 million debtors for non-MSMEs with a value of IDR 569.2 trillion. Meanwhile, the total restructuring for finance companies reached IDR 188.3 trillion from IDR 4.94 million contracts, while the restructuring value in microfinancial institutions reached IDR 26.4 billion including IDR 4.5 billion in Micro Waqf Bank.

The Financial Services Authority issued various counter-cyclical policies for banks, the capital market and the non-bank financial services industry. It aims to keep the Covid-19 pandemic from putting further pressure on the financial services industry to save the national economy and the livelihoods and welfare of the people. This policy was also implemented in support of Government actions to support in accelerating national economic recovery by prioritizing MSMEs and corporate debt restructuring.

The Financial Services Authority (OJK) maintains financial sector stability and support efforts to restore the national economy by issuing the following regulations:

(1) The Financial Services Authority Regulation Number 11/POJK.03/2020 is a one-pillar collectability policy for banking credit restructuring up to IDR 10 billion and it is prioritized for the most severely affected sector and MSMEs such as the online taxi drivers.

(2) The Financial Services Authority Regulation Number 48/POJK.03/2020 is a stimulus policy that takes effect until 31 March 2022. It grants an extension of credit restructuring to debtors affected by COVID19. Likewise, the Financial Services Authority Regulation Number 14/P0JK.05/2020 concerning the Countercyclical Policy on the Impact of the Spread of Coronavirus Disease 2019 for Non-Bank Financial Services Institutions. The validity period of the financing restructuring was later changed to Financial Services Authority Regulation Number 58/POJK.05/2020 so that the Financial Services Authority continues to improve supervision and implementation of policies that have been issued to maintain financial services sector stability amid the economic slowdown due to the impact of the COVID-19 pandemic.

(3) For the non-bank financial industry sector, the Financial Services Authority issued a restructuring policy through Regulation Number 14/P0JK.05/2020. This Financial Services Authority Regulation is a stimulus policy provided by the Financial Services Authority for the non-bank financial industry which is expected to maintain the stability of the non-bank financial industry and provide relief for debtors, especially finance companies with a value of below IDR 10 billion.

(4) Initially, this financing restructuring was effective up to December 31st, 2020 but then it was extended up to April 17th, 2022 based on the Financial Services Authority Regulation 58/POJK.05/2020 issued this December.

(5) OJK, LPS, Bank Indonesia and the Government also strengthened coordination in the implementation of Act No. 2 of 2020 relating to the operation of the lender.

To support the efforts to recover the national economy, Financial Services Authority has also issued various banking stimulus policies as follows:

(1) Postponement of the implementation of the third Basel standard to provide capital and liquidity adequacy for banks.

(2) Removal of Capital Conservation Buffer fulfilment obligation of 2.5\% Risk-Weighted Assets up to March 31st, 2021, which is also extended to March 31st, 2022, to provide capital adequacy for the banking industry.

(3) Decreasing the minimum limit of the Liquidity Coverage Ratio and Net Stable Funding Ratio to a minimum of $85 \%$ as of March 31st, 2022, aims to provide bank liquidity looseness.

(4) The postponement of assessing the quality of foreclosed collateral will be based on the latest quality up to March 31st, 2022 aimed to increase capital capacity.

(5) The decrease in allowance for general earning asset losses for rural banks and relaxation of interbank fund placements to increase capital capacity and provide lenient liquidity.

(6) Marketing of insurance products linked to investment with digital means to maintain sales of insurance products.

(7) Loan or financing restructuring policies for micro-financial institutions and Micro Waqf Banks to ease the burden on the community of micro-entrepreneurs. 
The stimulus of these regulations can control the quality of credit or the ratio of non-performing loans to Banks (Disemadi \& Shaleh, 2020). Therefore, it is necessary to effectively implement those various policies that have been issued to support national economic recovery through strengthening the financial services sector (Setiati \& Azwar, 2020). The total placement of funds has reached IDR 66.75 trillion, consisting of 4 Himbara Banks of IDR 47.5 trillion, 21 Regional Development Banks of IDR 16.25 trillion, and 3 Sharia Banks of IDR 3.0 trillion (Wahyudin, Hudaya \& Novriyandana, 2019). The total lending has reached IDR 280.96 trillion with the following details: 1.) Bank Himbara amounting to IDR 238.82 trillion; 2.) Regional Development Banks amounting to IDR 35.58 trillion; 3.) Islamic banks amounting to IDR 6.56 trillion. Leverage in lending for placement of funds has reached 4.21 times. MSMEs sector reached IDR 192.74 trillion or $68.6 \%$ of the total lending. The average ratio of non-performing loans owned by partner Commercial Banks is $2.98 \%$. Meanwhile, the average lending rate reached $2.1 \%$.

According to the annual report of Bank Indonesia, an existing solid buffer established before the pandemic helped to keep the financial system stable despite the accumulated pressures in the first semester of 2020. The Financial System Stability Index (FSSI) experienced some pressure, yet remained stable in the normal zone. Non-performing loans (NPL), which stood at $2.53 \%$ at the end of 2019 , increased slightly starting in the second quarter of 2020 to reach $3.11 \%$ in June 2020. Financial system stability remained sound, bolstered by strong buffers of solvency and liquidity, both in place before the pandemic, (BI annual report, 2020). In the second semester of 2020, financial system stability continued to improve in line with accommodative policies and less financial market uncertainty. The Financial System Stability Index (FSSI) remained stable in the normal zone below the prudential threshold. Ongoing implementation of the loan restructuring program also supported financial system stability. The NPL ratio was stable compared with conditions in the first semester of 2020 and remained below the threshold at 3.06\% (gross) in December 2020 and 0.99\% (nett) in November 2020 (Figure.1).

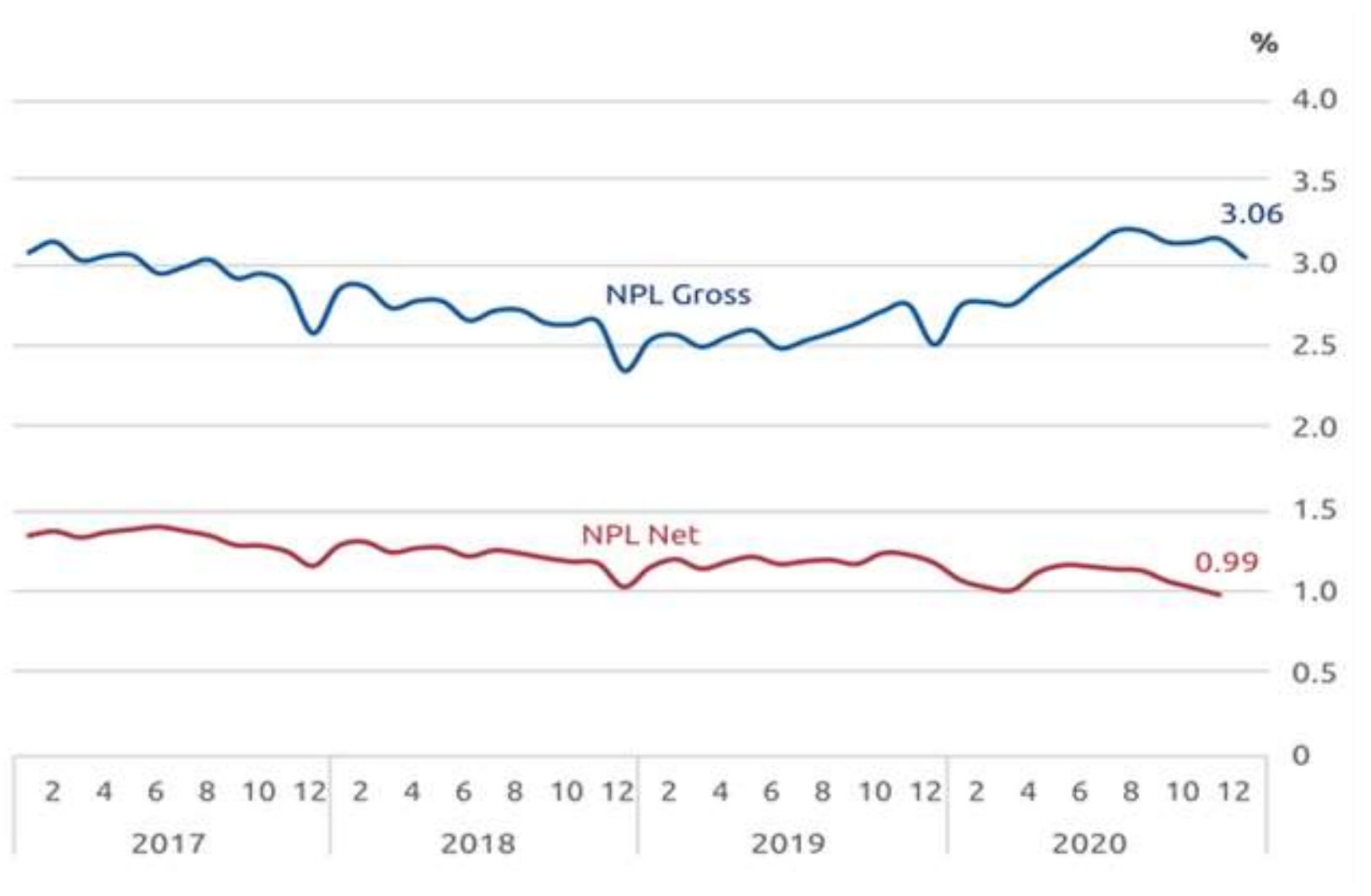

(Source: Bank Indonesia, Economic Report on Indonesia, 2020)

FIGURE 1: Non-Performing Loans (NPL)

The Financial Services Authority also supports the National Economic Recovery program, among others in the interest of subsidy policy, guarantees for Micro, Small, and Medium Enterprises, guarantees for corporations, and placement of government funds. On the monetary side, Bank Indonesia, among others, lowered the Bank Indonesia benchmark interest rate 7-day Reverse Repo Rate (7DRRR) by 25 basis points (bps) from 4.75\% to $4.5 \%$, and also provided additional liquidity by reducing demand deposits are required at a minimum of 50 bps rupiah. As the Bank Indonesia 7DRRR trend continued to decline, reaching 3.75\%, the Government issued the Minister of Finance's Regulation Number 64/PMK.05/2020 concerning Placement of Funds in Participating Banks in the Context of the National Economic Recovery Program. Moreover, through the Minister of Finance Regulation Number 64/2020, the government will place funds in Participating Banks to be given to Implementing Banks that carry out credit restructuring due to the impact of COVID-19, as well as to increase working capital loans for restructured debtors. 
The Indonesian Central Statistics Agency noted that the Indonesian economy in the second quarter of 2020 against the second quarter of 2019 experienced a growth contraction of 5.32\% (YoY) (Disemadi \& Shaleh, 2020). Another study by Pati (2020) explained that on November 5th, 2020, through the Central Statistics Agency, Indonesia again announced the Indonesian economy in the third quarter of 2020 to $-3.49 \%$ (YoY) showed that Indonesia experienced an economic recession. However, this figure is better than the second quarter of 2020 it was $-5.32 \%$ (YoY). The Indonesian Governments' projects economic growth in 2020 in the range of $-1.7 \%$ to $-0.6 \%$ (YoY) (Supriatna, 2020).

Mentari \& Putri (2020) stated that the financial services sector has gone through a survival phase amid the COVID-19 pandemic until the first half of this year, and it is time to enter the recovery stage in the second semester, in line with the implementation of various policy stimulus packages in the fiscal, monetary, and fiscal sectors. and the financial sector. The Financial Services Authority noted that credit growth during the second quarter of 2020 was monitored positively, even though it was a thin 1.49\% (YoY) or slowed down from $2.77 \%$ (YoY) the previous month. In the first semester of 2020, the bank's gross non-performing loan was 3.11\%, up from 3.01\% in May 2020 due to the COVID-19 pandemic. To complement the relaxation policy restructuring and credit or financing quality assessment for Banks and finance companies, the Financial Services Authority has postponed the implementation of Basel three reforms related to easing the fulfilment of liquidity indicators and capital indicators.

The results of analysis by Surpriatna (2020) disclosed by the Financial Services Authority on December 28th, 2020, show that until November 30th, 2020 the total COVID-19 restructuring credit continued to increase to IDR 951.2 trillion from about 7.53 million debtors in banking consisting of 5.80 million Micro, Small, and Medium Enterprise's debtors with a value of IDR 382 trillion, and 1.73 million non-Business, Micro, Small, and Medium Enterprises debtors with a value of IDR 569.2 trillion. Meanwhile, the total restructuring for finance companies up to December 15th, 2020 reached IDR 188.3 trillion from IDR 4.94 million contracts, while the restructuring value in Micro Financial Institutions reached IDR 26.4 billion, including IDR 4.5 billion in Micro Waqf Bank (Lasnita \& Main, 2020).

\section{- Economic and Banking Conditions in Indonesia Amid the COVID-19 Pandemic}

To date, the total number of COVID-19 cases have reached 141 million and spread around the world. Fortunately, Indonesia's recovery rate reached $81.9 \%$, which is higher than the global average recovery rate (Trisia, 2020). This can be achieved due to strict health protocols even though public activities have been eased to a certain extent. The Indonesian economy passed its rock bottom in the third quarter of 2020, which was contracted by $-3.49 \%$ (YoY). This figure is still better compared to several other countries which still are being contracted by more than 4\%. The upward trend was seen in domestic consumption and inflation that strengthen the foundations for economic recovery from the demand side (Shabib \& Irwandi, 2016).

The agricultural sector, education services, information, and communication, as well as health services and social activities, managed to survive and recorded positive growth in the third quarter of 2020. On the external side, the trade balance surplus continued in October 2020. This surplus condition led to improvements in the current account. Indonesia managed to experience a surplus for the first time in a decade (Wahyudin, Hudaya \& Novriyandana, 2019). Indications of economic recovery also come from the financial sector, which is shown by the performance of the Composite Stock Price Index, the exchange rate, and foreign capital flows which continue to increase where the financial sector stock index has managed to grow by $58 \%$ after a sharp decline so that there is optimism that this financial sector will support economic activity in the real sector to encourage the economy to continue to grow. However, the COVID-19 pandemic has also raised new challenges (Susilawati, Falefi \& Purwoko, 2020).

Banks have also conducted restructuring of 7.5 million debtors worth IDR 936 trillion, consisting of 5.8 million debtors for Micro, Small, and Medium Enterprises worth IDR 371.1 trillion, while finance companies, per October 27th, 2020 has restructured IDR 4.79 million in restructuring contracts worth IDR 177.66 trillion. Fiscal policy for 2021 through the State Expenditure Budget will also be directed to support the acceleration of recovery and transformation of the Indonesian economy which includes education, health, social protection, infrastructure, food security, tourism, as well as technology, information, and communication, in which various combinations of these policies are expected to be economic. Indonesia can grow in the range of $4.5 \%$ to $5.5 \%$ in 2021 with inflation maintained at around $3 \%$.

\section{- Positive Domestic Economic Indicators}

Economic Report on Indonesia issued by Bank Indonesia stated that the banking industry maintained a solid capital position. It can be seen in Figure 2 below showing a high Capital Adequacy Ratio (CAR) of 24.13\%, which is well above the threshold. The ratio of liquid assets to deposits continued to rise, reaching $31.67 \%$. It measures the liquidity in the banking system. Banking industry performance was maintained in line with efficiency and profitability, as reflected by a BOPO efficiency ratio of $86.04 \%$ and various profitability indicators, including the net interest margin (NIM) and return on assets (ROA) at 4.29\% and 1.63\%, respectively in November 2020 . The banking industry maintained a solid capital position, with a high Capital Adequacy Ratio (CAR) of 24.13\%, which is well above the threshold (Figure 2). As a measure of liquidity in the banking system, the ratio of liquid assets to deposits continued to rise, reaching $31.67 \%$. 


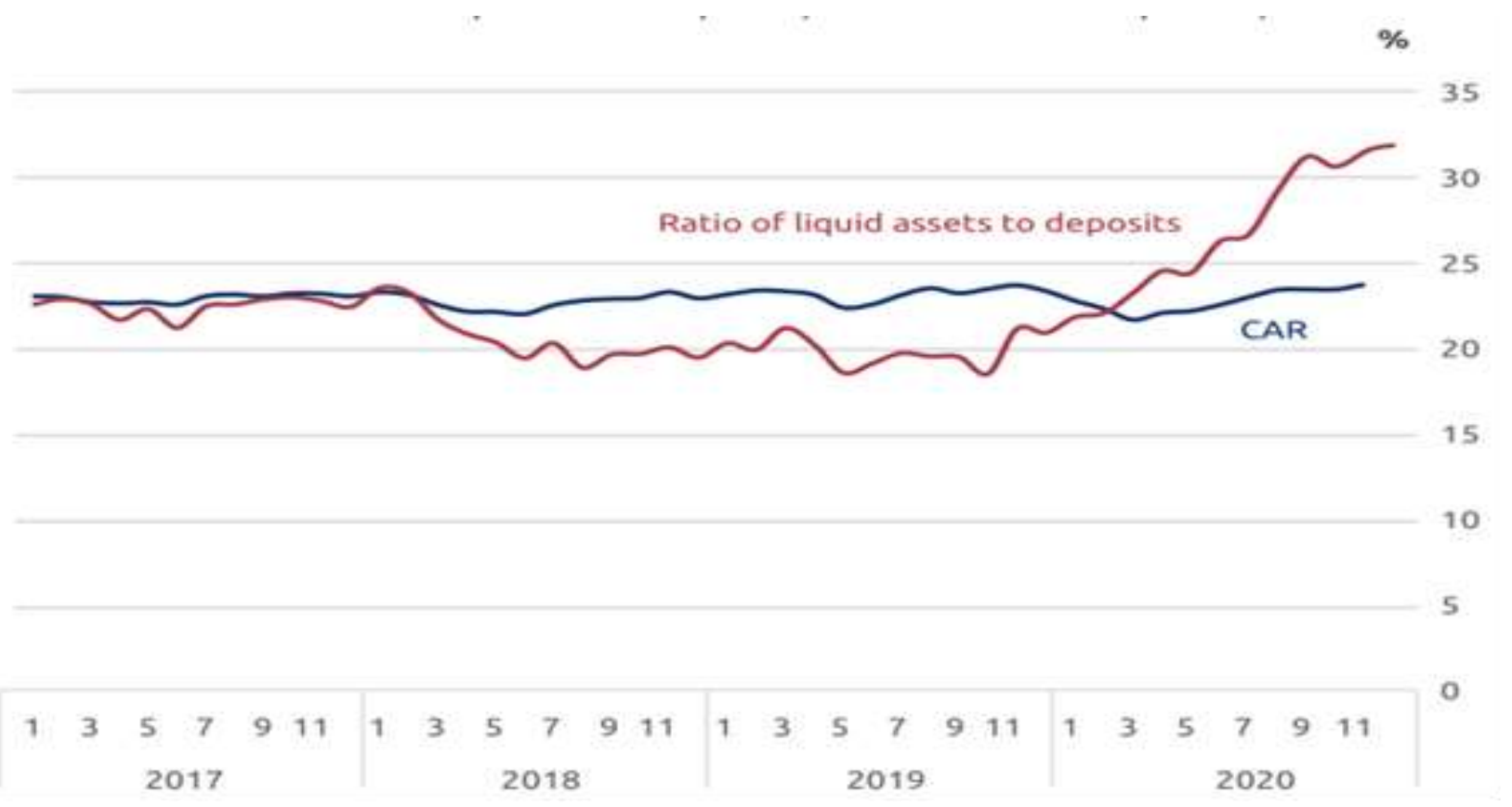

(Source: Bank Indonesia, Economic Report on Indonesia, 2020)

FIGURE 2: Bank Capital Adequacy Ratio and Liquidity Ratios

Bank liquidity increased in line with expansionary fiscal policy and accommodative monetary and macroprudential policy, as reflected by the ratio of liquid assets to deposits which reached $26.24 \%$ in June 2020. Besides, financial system resilience remained solid on robust bank capital, as confirmed by a Capital Adequacy Ratio (CAR) of 22.50\% in June 2020, well above the prudential threshold (Bank Indonesia, 2020).

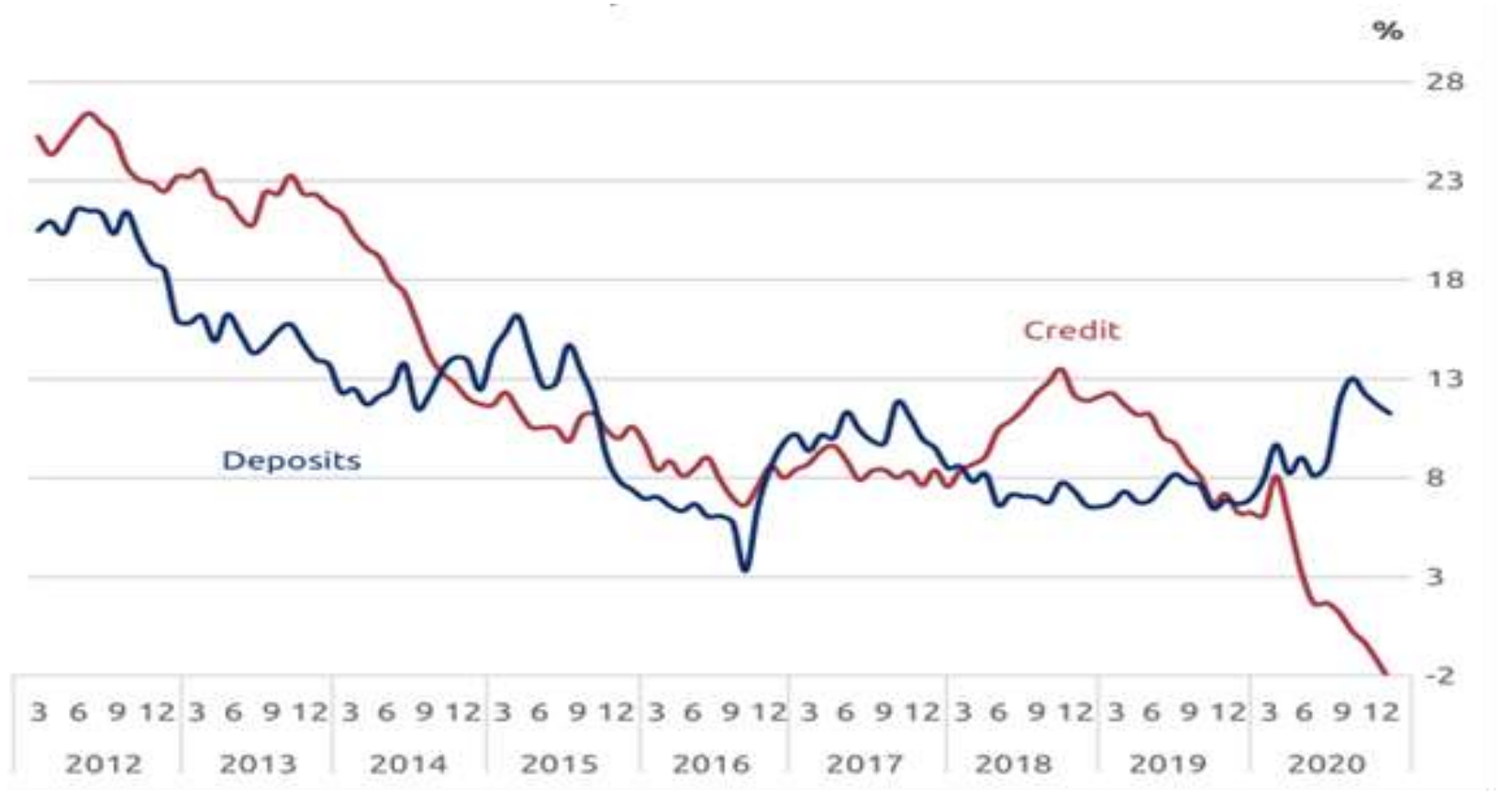

(Source: Bank Indonesia, Economic Report on Indonesia, 2020)

\section{FIGURE 3: Credit and Deposits}

In the second semester of 2020, economic growth in Indonesia started to rebound as the Government applied relaxation of large-scale social restrictions. The realizations of the fiscal stimulus increased and the global economy continued to improve. In addition, effective healthcare management and implementation of health protocols allowed the Government to incrementally unwind large-scale social restrictions, causing mobility to increase gradually, (Bank Indonesia, 2020). The Bank Indonesia report further stated that Government spending also has been increased especially in the form of social aid disbursements; procurement of other goods and services; regional transfers and village fund disbursements. The spending was reflected in robust government consumption growth in the latter half of the year. The fiscal stimuli have helped to safeguard consumption, particularly amongst the low-income citizens. The implementation of the National Economic Recovery Program as of 9 December 2020 has made significant progress in supporting the financial services industry, including the provision of funds and restructuring of credit/financing (Caraka, et. al., 2020). 


\section{CONCLUSION}

The ongoing COVID-19 pandemic becomes an enormous challenge for all public and private sectors including banking credit at domestic and global levels. The results of this study indicate that the Indonesian Financial Authority Services Regulations have shown positive impacts in supporting the country economic recovery. The regulations relaxed banking credit and provided stimulus to bank debtors and they are proven to be effective and show some good results. The issuance and implementation of the financial policies and monitoring instruments have prevented the wider impact of the COVID-19 pandemic on the economy and the financial sector especially for the public, informal sector and Micro, Small, and Medium Enterprises. The results of this study indicate that the regulations maintain the stability of the financial system. As stated in the 2020 Economic Report on Indonesia published by Bank Indonesia, the financial system is well-maintained because the regulations issued by Financial Services Authority have been implemented effectively to support the national economic recovery policy by the Government of the Republic of Indonesia. Thus, this study confirms that the Keynesian economics theory stating that in an economic crisis or recession, expansionary fiscal policy can stimulate economic activity. Nevertheless, the crisis is still unpredicted, it is far from over. All countries should stay alert and keep the best-proven measures taking place to ensure economic stability and people welfare.

\section{RECOMMENDATION AND LIMITATION}

The Financial Services Authority regulations are proven to be beneficial and can assist financial services institutions in mitigating risks and helping business actors to continue their business activities during the pandemic. This study is still limited to the literature analysis of the results from previous studies only, therefore more empirical and quantitative studies are still needed to explore the depth of research data and information. The authors recommend that the Financial Services Authority should continue strengthening coordination with all stakeholders to maintain the financial system stability and continue to carry out various synergistic policies to maintain the stability of the real sector and the financial services sector to accelerate efforts to recover the economy.

Various relevant policies should be implemented to support the national economic recovery program, including 1.) Exchange of data and information on bank debtors for the provision of interest subsidies; 2.) Coordinating the formulation of bank credit guarantee implementation; 3.) Coordination and supervision of the implementation of Placement of Government Funds in the framework of National Economic Development in various Banks; 4.) Coordinating and encouraging the provision of People's Business Credit specifically affected by the pandemic and the implementation of the restructuring of People's Business Credit.

\section{ACKNOWLEDGEMENT}

The author expresses his gratitude to several parties, including Bank Indonesia, the Financial Services Authority, and the Government of Indonesia who has been willing to share the data and information needed for this study and the author hopes that the results of this study will provide benefits both academically and practically.

\section{REFERENCES}

[1] Adhikari, S. P., Meng, S., Wu, Y. J., Mao, Y. P., Ye, R. X., Wang, Q. Z. \& Zhou, H. (2020). Epidemiology, Causes, Clinical Manifestation and Diagnosis, Prevention and Control of Coronavirus Disease (COVID-19) During the Early Outbreak Period: A Scoping Review. Infectious Diseases of Poverty, 9(1), 1-12.

[2] Al-Nimri, A. \& Altarawneh, Y. (2020). Understating the Impact of Economic Factors on Stock Yield: Jordanian Stock Market Case. International Journal of Economics and Financial Issues, 10(6), 1-4. DOI: https://dx.doi.org/10.32479/ijefi.10415

[3] Anderson, R. M., Heesterbeek, H., Klinkenberg, D., \& Hollingsworth, T. D. (2020). How Will Country-Based Mitigation Measures Influence the Course of the COVID-19 Epidemic? The Lancet Infectious Diseases, 3(1), 931-934. DOI: https://dx.doi.org/10.1016/S01406736(20)30567-5

[4] Bank Indonesia, 2020. Synergize to Build Optimism for Economic Recovery. Economic Report on Indonesia.

[5] Barcelo, D. (2020). An Environmental and Health Perspective for COVID-19 Outbreak: Meteorology and Air Quality Influence, Sewage Epidemiology Indicator, Hospitals Disinfection, Drug Therapies, and Recommendations. Journal of Environmental and Chemical Engineering, 8(4), 104-107.

[6] Caraka, R. E., Lee, Y., Kurniawan, R., Herliansyah, R., Kaban, P. A., Nasution, B. I., Gio, P. U., Chen, R. C., Toharudin, T., Pardamean, B. (2020). Impact of COVID-19 Large Scale Restriction on Environment and Economy in Indonesia. Global Journal of Environmental Science and Management, 6(1): 65-84.

[7] Creswell, J. W. (2017). Research Design: Qualitative, Quantitative, and Mixed Methods Approaches. London: Sage Publications. 
[8] Disemadi, H. S. \& Shaleh, A. I. (2020). Banking Credit Restructuring Policy on the Impact of COVID-19 Spread in Indonesia. Jurnal Inovasi Ekonomi, 5(2), 63-70

[9] Djalante, R., Lassa, J., Setiamarga, D., Sudjatma, A., Indrawan, M., Haryono, B., Mahfud, C., Sinapoy, M. S., Djalante, S., Rafliana, I., Gunawan, L. A., Surtiari, G. A. K. \& Warsilah, H. (2020). Review and Analysis of Current Responses to COVID-19 in Indonesia: Period of January to March 2020. Progress in Disaster, 6, 19. DOI: https://dx.doi.org/10.1016/j.pdisas.2020.100091

[10] Donthu, N. \& Gustafsson, A. (2020). Effects of COVID-19 on Business and Research. Journal of Business Research, 117, 284-289. DOI: http://dx.doi.org/10.1016/j.jbusres.2020.06.008

[11] Goodell, J. W. (2020). COVID-19 and Finance: Agendas for Future Research. Finance Research Letters, 35, 101-512. DOI: https://dx.doi.org/10.1016/j.frl.2020.101512

[12] Guerrieri, V. et al. (2020), Macroeconomic Implications of COVID-19: Can Negative Supply Shocks Cause Demand Shortages?

[13] Gusti, G. P. (2020). Is There Any Impact of Electronic Money to Increase Knowledge of Financial Literacy?: In the Pandemic Situation Of COVID-19 in Pontianak City. MECJ: Malaysian E-Commerce Journal, 4(2), 4853. DOI: https://dx.doi.org/10.26480/mecj.02.2020.48.53

[14] Hayes, A. (2020). Stimulus Package Explained. Retrieved from https://rocketfcu.com/stimulus-packageexplained

[15] Halkia, M., Ferri, S., Schellens, M. K., Papazoglou, M. \& Thomaskos, D. (2020). The Global Conflict Risk Index: A Quantitative Tool for Policy Support on Conflict Prevention. Progress in Disaster Science, 6, 1-22. DOI: http://dx.doi.org/10.1016/j.pdisas.2020.100069

[16] Horton, R. (2020). Offline: COVID-19 and the NHS - “A National Scandal”. The Lancet, 39(5), 10-22.

[17] Lassa, J. (2019). Negotiating Institutional Pathways for Sustaining Climate Change Resilience and Risk Governance in Indonesia. Climate, 7(8), 95-102. https://doi.org/10.3390/cli7080095

[18] Lasnita, F. A. \& Utama, M. A. R. (2020). Authorized Failure: How is Company Status?. Indonesian Journal of Advocacy and Legal Services, 2(2), 223-242. https://doi.org/10.15294/ijals.v2i2.37721

[19] Li, Q., Guan, X., Wu, P., Wang, X., Zhou, L., Tong, Y., Ren, R., Leung, K. S. M., Lau, E. H. Y., Wong, J. Y., Xing, X., Xiang, N., Wu, Y., Li, C., Chen, Q., Li, D., Liu, T., Zhao, J., Liu, M., Tu, W., Chen, C., Jin, L., Yang, R., Wang, Q., Zhou, S., Wang, R., Liu, H., Luo, Y., Liu, Y., Shao, G., Li, H., Tao, Z., Yang, Y., Deng, Z., Liu, B., Ma, Z., Zhang, Y., Shi, G., Lam, T. T. Y., Wu, J. T., Gao, G. F., Cowling, B. J., Yang, B., Leung, G. M. \& Feng, Z. (2020). Early Transmission Dynamics in Wuhan, China, of Novel Coronavirus-Infected Pneumonia. New England Journal of Medicine, 382, 1199-1207 DOI: https://dx.doi.org/10.1056/NEJMoa2001316

[20] Lupia, T., Scabini, S., Pinna, S. M., Di Perri, G., De Rosa, F. G. \& Corcione, S. (2020). 2019 Novel Coronavirus (2019-Ncov) Outbreak: A New Challenge. Journal of Global Antimicrobial Resistance, 21, 22-27. DOI: https://dx.doi.org/10.1016/j.jgar.2020.02.021

[21] Marks, S.V. (2017). Non-Tariff Trade Regulations in Indonesia: Nominal and Effective Rates of Protection. Bulletin of Indonesian Economic Studies, 53(3), 333-357.

[22] Megatsari, H., Laksono, A. D., Ibad, M., Herwanto, Y. T., Sarweni, K. P., Geno, R. A. P. \& Nugraheni, E. (2020). The Community Psychosocial Burden During the COVID-19 Pandemic in Indonesia. Heliyon, 6, 1-5. DOI: https://dx.doi.org/10.1016/j.heliyon.2020.e05136

[23] Mentari, N. \& Putri, U. T. (2020). Risk Mitigation of Disease Pandemic in the Indonesian Banking Industry: In Response to COVID-19. Lentera Hukum, 7(3), 245-266.

DOI: https://dx.doi.org/10.19184/ejlh.v7i3.20146

[24] Pati, U. K. (2020). Indonesian Government Policy in Mitigating Economic Risks Due to the Impact of the COVID-19 Outbreak. Journal of Law and Legal Reform, 1(4), 577-590. https://dx.doi.org/10.15294/jllr.v1i4.39539

[25] Setiati, S., \& Azwar, M. K. (2020). COVID-19 and Indonesia. Acta Medica Indonesiana, 52(1), 84-89. 
[26] Shabib, H. M. \& Irwandi, S. A. (2016). Violation Regulation of Financial Services Authority, Financial Performance, and Corporate Social Responsibility Disclosure. Journal of Economics, Business, and Accountancy Ventura, 19(1), 141-154.

[27] Supriatna, E. (2020). Socio-Economic Impacts of the COVID-19 Pandemic: The Case of Bandung City. Journal of Governance, 5(1), 61-70. DOI: https://dx.doi.org/10.31506/jog.v5i1.8041

[28] Susilawati., Falefi, R. \& Purwoko, A. (2020). Impact of COVID-19's Pandemic on the Economy of Indonesia. BIRCI-Journal: Budapest International Research and Critics Institute-Journal, 3(2), 1147-1156. DOI: https://dx.doi.org/10.33258/birci.v3i2.954

[29] Taylor, S. J., Bogdan, R. \& DeVault, M. (2015). Introduction to Qualitative Research Methods: A Guidebook and Resource. John Wiley \& Sons.

[30] Trisia, I. (2020). The Evaluation of Countercyclical Policy Implementation in Facing the Impact of the Spread of COVID-19: Study on Central Kalimantan Bank Pension Fund. Budapest International Research and Critics Institute-Journal, 3(4), 3483-3493.

[31] Trisliatanto, D. A. (2020). Research Methodology: A Complete Guide to Research with Ease. Yogyakarta: ANDI Publisher.

[32] Wahyudin, N., Hudaya, M. \& Novriyandana, R. (2019). Financial Statements Disclosure on Indonesian Local Government Websites. Asian Journal of Accounting Research, 4(1),112-128.

DOI: https://dx.doi.org/10.1108/AJAR-06-2019-0043

[33] Yong, M. \& Xingkai, L. (2016), Financial Development and the Effectiveness of Monetary Policy. Journal of Banking and Finance, 68(1), 1-11. 